\title{
WAYS OF IMPROVING THE PREPARATION OF PRIMARY SCHOOL TEACHERS IN TERMS OF THE NEW UKRAINIAN SCHOOL
}

\author{
Liubov Nos \\ Ivan Franko National University of Lviv, \\ Tuhan-Baranovskoho Str., 7, Lviv, Ukraine, UA-79005
}

The ways of improving the preparation of primary school teachers in terms of the New Ukrainian School are illuminated in the article. The proactive approach to the training of future teachers becomes topical. Issues of updating content, forms and methods of student training and methodological advancement of their preparation require creative solution. Special attention is given to consideration of the problem of person-centred education of future professionals. The basic principles for the implementation of personcentred education in high school is considered as well. The author highlights that under such conditions, personality may be formed harmoniously and develop comprehensively, disclosing its creative abilities in full. One of the ways that enables students to improve their skills is to introduce innovative teaching methods.

University teachers should create conditions for the formation of innovative culture of school teachers of a new generation, capable of searching, selecting and using important materials for further pedagogical activity. Such an approach will raise students' awareness of innovations in the field of education and will show them the peculiarities of using innovative techniques while teaching young children.

The author states that one of the main ways of improving the content of teacher training is the widespread application of information and communication technologies. It helps to increase cognitive activity of students. An important aspect of improving the training of teachers is the establishment of a partnership between the faculties of pedagogical education and schools as well as the intensification of cooperation between university teachers and primary school teachers in practical terms, particularly in holding the joint scientific and practical workshops. A good example of such cooperation is making agreements with certain schools predetermined to serve as the bases for student teaching practice, and thus creating appropriate conditions for the latter.

It is emphasized that in transitioning of primary school to the integrated learning, it is important to extend the terms of pedagogical student practice. It will help graduates better learn modern methods of teaching in a primary school and learn how to create academic environment based on proactive competence approaches.

The article draws attention to the problems of preparation of future specialists to work with pupils with special educational needs and to the professional selection of school graduates to the Ukrainian higher educational pedagogical institutions.

Key words: innovative activity, personal development, personality-oriented technique, innovative technology, active learning methods.

(C) Nos L., 2018 
ISSN 2078-5526. Вісник Львівського університету. Серія педагогічна. 2018. Випуск 33

The New Ukrainian School is the school that teaches to live in the $21^{\text {st }}$ century. According to this concept, students acquire knowledge rather than consume it. The task of the teacher is to become a partner, assistant to students, encourage them to have a critical thinking over the material they are studying, develop their interest in learning, as well as teach to properly apply their knowledge. The New Ukrainian School is expected to prepare responsible citizens capable of realizing their potential in the modern world.

In these conditions, the proactive approach to the training of primary school teachers becomes topical. Issues of updating content, forms and methods of students' training, methodological advancement of their preparation require creative solution.

The study of scientific sources has proved that in the sphere of pedagogics much attention is paid to the problem of primary school teachers' preparation for their future professional activity. Various aspects of the training of future specialists are covered by such researches as O. Bida, O. Budnyk, M. Vashulenko, O. Dubaseniuk, L. Koval, A. Kolomiyets, S. Martynenko, N. Machynska, O. Savchenko, M. Stakhiv, L. Khomych, L. Horuzha, and others.

The goal of the article is to define novel approaches to the preparation of primary school teachers in terms of implementation of the concept of The New Ukrainian School.

Researches dealing with modern aspects of professional teacher training specify that the problem of forming the professional competence in future primary school teachers is becoming topical. The peculiarity of the profession of primary school teachers lies in applying competence- and personality-oriented technique in teaching young children.

In view of this, teacher training faculties should direct the educational process to the development of students' personality. A personality-oriented educational system can provide modern school with active, highly-professional specialists, who are ready to undergo regular changes.

There are some principles higher school should certainly take into consideration. They are as following:

- principle of individuality, self-esteem on part of the student, who is the subject of the educational process;

- correlation between educational technologies at all levels of educational process and regularities of personal professional development;

- advancing character of education, which ensures the formation of professional competence of a future specialist;

- taking into account students' personal experience, their needs for selfrealization, self-determination, self-development;

- constant harmonization of students\&apos; experience with the scientific content of the acquired knowledge. 
Under such conditions, personality may be formed harmoniously and develop comprehensively, disclosing its creative abilities in full.

In our opinion, the personality-oriented approach contributes to the spiritual enrichment of a person, the formation of its value orientations, which manifest via such indicators as responsibility, tolerance, decency, patience, honesty, justice, objectivity, high moral quality, kindness. It is important for higher educational school to find approaches to training professionals who can study throughout life and make decisions in favour of a child. It is important to emphasize that personal qualities of a primary schools teacher will greatly influence his effective practical activity in school.

The personality-oriented approach will contribute to the establishment of a qualitatively new relationship between teachers and students. Therefore, it is important to establish such a system of work for higher educational teacher training institutions, which would provide guidance on students' individual work aimed at creative search, at elaboration of educational projects. Such approaches will promote self-improvement of students by deepening their knowledge [4, c. 93 ].

We believe that one of the ways that enables students to improve their skills is to introduce innovative teaching methods. "Implementation of innovations in the sphere of education, says O. Dubaseniuk, is a complex process, which involves gradual updating and improvement of content, methods, tools, and pedagogical techniques, which, of course, influences the quality of the pedagogical process" [2]. She notes that "The need for innovative direction of pedagogical activity at the present stage of development of education and society is due to a number of factors". Among them there are two the most important. The first factor deals with the social and economic transformations and the scientific and technological process that predetermine the need for radical renovation of the system of higher education, methods and tools of educational process accomplishment in higher educational institutions. The innovative approach to the teachers - students cooperation involves creation, development and application of pedagogical novelties, serves as a means of updating educational policy. Secondly, strengthening the humanity-oriented direction of education, constant change of volume and content of disciplines, introduction of new specialties, new subjects, elective courses require constant search for new forms of organization of the educational process, for new tools of learning. In this respect, increases the role of the teacher as a generator of pedagogical ideas [1].

We agree with the opinion of O. Pometun, who claims that "the innovative readiness of the teacher, that is, the desire and ability to use new pedagogical techniques and construct own ones, should be considered and formed as the most important component of his professional competence. The main factors of innovative teacher training are the development of his individual working style, 
openness to everything new, conscious attitude to the introduced innovations, since mastering something new always occurs at the personality level" [6, c. 25].

In view of this, it is important to take into consideration the innovative changes in the educational sphere and to rebuild system of preparation of future specialists. University teachers should create conditions for the formation of innovative culture of school teachers of a new generation, capable of searching, selecting and using important materials for further pedagogical activity. To our mind, this first of all concerns pedagogical courses (e.g., "Introduction to Specialty with the Fundamentals of Pedagogy", "Fundamentals of Pedagogical Skills", "History of Pedagogy, Theory and Methods of Education", "Didactic and Pedagogical Techniques in Primary School", "Comparative Pedagogy") and methodological courses ("Methods of Teaching the Ukrainian language", "Methods of Teaching English", "Methods of Teaching Mathematics") in the process of doing which students should learn about modern innovative techniques used in primary school. Such an approach will raise students' awareness of innovations in the field of education and will show them the peculiarities of using innovative techniques while teaching young children.

One of the main ways of improving the content of teacher training at the present stage is the widespread application of information and communication technologies. We have detected that information and communication technologies increase students' cognitive activity, bring significant changes into their individual academic work.

An important aspect of improving the training of teachers is the establishment of a partnership between the faculties of pedagogical education and schools, and the intensification of cooperation between university teachers and primary school teachers in practical terms, in particular, in holding the joint scientific and practical workshops. This will encourage scholars to conduct scientific researches and provide teachers with new methodological approaches based on reliable scientific results. Close cooperation between university researchers and school teachers on the one hand will promote the improvement of school curricula, and on the other hand will serve as the basis for further scientific researches on the part of university staff in order to make changes to the curricula of preparation of future teachers.

A good example of such cooperation is making agreements with certain schools predetermined to serve as the bases for students' teaching practice, and thus creating appropriate conditions for the latter. This helps to develop professional knowledge and communicative skills necessary of future teachers, provide comprehensive growth of their personality, disclosure of creative abilities, acquisition of an individual style. It is important to establish regular contacts with teachers, to systematically carry out an analysis of the academic achievements of future specialists and their professional development. Step-by-step conducting of 
pedagogical practice allows students of pedagogical faculties to adapt to school, to observe pupils' behavior and develop skills to act creatively in different situations.

In the conditions of transition of primary school to integrated learning, it is important to extend the terms of students' pedagogical practice. This is emphasized in the Concept of Pedagogical Education Development, in particular, it is proposed to conduct continuous practice (starting from the first year of study, in different educational institutions and in different classes). The volume of practical training should be at least 30 ECTS credits within the mandatory part of the baccalaureate programs. It is highlighted that "At least half of the volume of practical training should be allocated for the training practice with individual completion of professional tasks" [3]. We believe that experienced teachers, especially those who are certified trainers for the New Ukrainian School, should be involved into students' pedagogical practice. It will help graduates better learn modern methods of teaching in primary school and learn how to create academic environment based on proactive competence approaches and principles of "partnership pedagogy".

There are some urgent unsolved issues in the higher pedagogical school, in particular the ones related to the preparation of future specialists to work with pupils with special educational needs. It is particular acute now, when inclusive classes are being created. Teachers face the problem of finding proper methods and tools to organise educational process in such a class. Therefore, it is important to expand the content of syllabuses and curricula, to intensify the work of university teachers in terms of developing methodological and teaching materials aimed at preparation of primary school teacher to work with pupils with special educational needs.

We would like to draw attention to another important issue, solution of which would improve the quality of future specialists training. It is a question of the professional selection of schools graduates to Ukrainian higher educational pedagogical institutions. As for the present, applicants enter higher education institutions on the basis of the ZNO certificates, submitting their application via the Internet. The study of foreign experience, in particular Canadian, shows that the admission to pedagogical specialties is a difficult and effort-consuming process. Applicants must give strong reasons for their choice of teaching profession; moreover, those applicants who have some experience of work with children of primary school age have certain advantages. It seems quite possible that such rules of enrolment to the pedagogical faculties could be borrowed and used in Ukrainian higher pedagogical school. A valuable idea, in our opinion, is to conduct interviews with applicants to the specialty "Primary Education" to detect their personal psychological and pedagogical skills and abilities (creative thinking, life values, organizational and strong-willed qualities). School realities show that some students are afraid to conduct lessons to primary school children during their pedagogical practice. They become aware of the falsity of their choice and leave 
ISSN 2078-5526. Вісник Львівського університету. Серія педагогічна. 2018. Випуск 33

the educational institution. Here, the British experience may be at help: students specializing in "Primary Education" have pedagogical practice at school during the first two weeks of their study. This gives an opportunity to make sure whether their choice of profession was correct.

Language defects of primary school teacher are inadmissible. Because this is where the bases of the young learner's language culture are formed. Therefore, it is advisable to check the language culture (absence of speech defects, expressiveness, emotionality) of the entrants. At the same time, it should be emphasized that in Ukraine there is a positive experience of the Poltava Pedagogical Institute, where in 1980's, under the guidance of rector I. A. Zyazyun, a system of proficiency selection of entrants was developed, which considered the conformity of personality characteristics to professional requirements. They also held a creative interview to identify pedagogical gift of the entrant [5, c. 149-150].

Conclusions. So, in order to prepare future teachers for activities in terms of updating the content of primary school education, it is necessary to create a whole range of new methodological approaches that will contribute to the formation of innovative culture of the teacher, positive attitude to novelties, formation of crtitical thinking, awareness of practical significance of the innovations, creation of conditions for teacher training students' self-development and self-education. An important component in the training of future teachers is the introduction of a personality-oriented approach in the educational process.

Further development of cooperation between university teachers and primary school teachers, extending the terms of students' pedagogical practice will enable future teachers to become highly qualified professionals eager to educate - both teach and guide - young learners.

1. Дубасенюк $O$. A. Інноваційні навчальні технології - основа модернізації університетської освіти // Освітні інноваційні технології у процесі викладання навчальних дисциплін: зб. наук.-метод праць / За ред. О. А. Дубасенюк; Вид-во ЖДУ ім. І. Франка. - Житомир, 2004. - С. 3-14.

2. Дубасенюк $O$. А. Інновації в сучасній освіті // Інновації в освіті: інтеграція науки і практики: збірник науково-методичних праць / за заг. ред. О. А. Дубасенюк; Вид-во ЖДУ ім. І. Франка. - Житомир, 2014. - С. 12-28.

3. Концепція розвитку педагогічної освіти [Електронний ресурс]. Режим доступу:https://mon.gov.ua/ua/npa/pro-zatverdzhennya-koncepciyirozvitku-pedagogichnoyi-osviti

4. Нос Л. С. Проблеми підготовки вчителя в сучасній педагогічній науці / Нос Л.С. // Наук. вісн. Мукачівського держ. ун-ту. Серія «Педагогіка та психологія». - 2016. - Вип. 2 (4). - С. 92-96. 
Liubov Nos

ISSN 2078-5526. Вісник Львівського університету. Серія педагогічна. 2018. Випуск 33

5. Нос Л. С. Підготовка вчителя в Канаді: теорія і практика: навч. посіб. / за ред. Н.Г. Ничкало. - Львів. - Бадікова Н. О., 2016. - 254 с.

6. Пометун $O$. Технології - це відповідь. А про що ми запитуємо? / Пометун О // Рідна школа. - 2011. - № 8-9. - С. 23-26.

Стаття: надійшла до редколегї 07.09.2018

доопрацьована 19.11.2018

прийнята до друку 05.12.2018

\title{
ШЛЯХИ УДОСКОНАЛЕННЯ ПІДГОТОВКИ МАЙБУТНІХ ВЧИТЕЛІВ ПОЧАТКОВОЇ ШКОЛИ В УМОВАХ НОВОЇ УКРАЇНСЬКОЇ ШКОЛИ
}

\author{
Любов Нос \\ Львівський наиіональний університет імені Івана Франка, \\ вул. Туган-Барановського, 7, Львів, Украӥна, 79005
}

Висвітлено підходи до удосконалення підготовки майбутніх вчителів початкової школи в умовах Нової української школи. Наголошено на необхідності творчого вирішення питання оновлення змісту, форм та методів підготовки студентів, вдосконалення їхньої методичної підготовки. Визначено основні напрями у системі підготовки майбутніх фахівців. Описано особистісно орієнтований підхід, який сприяє формуванню ціннісних орієнтирів студентів, утвердженню якісно нових відносин між ними та викладачами. Зазначено, що одним із шляхів для удосконалення навичок студентів $є$ впровадження інноваційних методів навчання. Головними чинниками інноваційної підготовки вчителя $\epsilon$ розвиток його індивідуального стилю діяльності, відкритість до нового, усвідомлене ставлення до впроваджуваної інновації. 3'ясовано, що широке застосування інформаційнокомунікаційних технологій підвищує активність пізнавальної діяльності студентів, вносить суттєві зміни в організацію їхньої самостійної роботи. Вагомим аспектом удосконалення підготовки вчителів $\epsilon$ налагодження партнерства факультетів педагогічної освіти 3 школами та поглиблення співпраці викладачів університету і вчителів початкової школи в практичному аспекті, зокрема, проведення спільних науково-практичних семінарів. Добрим показником співпраці є укладання угод 3 базовими школами для проведення практики студентів, створення для них відповідних умов. Це сприяє виробленню умінь та навичок професійної діяльності, розвитку комунікативних здібностей майбутніх учителів, забезпечує всебічний розвиток особистості, повне розкриття ії творчих сил, набуття індивідуального стилю. Автор акцентує увагу на тому, що в умовах переходу початкової школи на інтегроване навчання важливо збільшити терміни проходження педагогічної практики студентів, залучати досвідчених вчителів-практиків до іiі організації. Висвітлено проблеми підготовки майбутніх фахівців до роботи 3 дітьми 3 особливими освітніми потребами. Привернуто увагу до проблеми професійного відбору випускників шкіл до українських закладів педагогічної освіти.

Ключові слова: інноваційна діяльність, особистісний розвиток, особистісно орієнтована технологія, активні методи навчання. 